\title{
DIAGNOSIS AND TREATMENT OF BENIGN LIVER NODULES: Brazilian Society of Hepatology recommendations
}

\author{
Edna STRAUSS ${ }^{1}$, Adalgisa de Souza Paiva FERREIRA², Alex Vianey Callado FRANÇA ${ }^{3}$, \\ Andre Castro LYRA4, Fabio Marinho do Rego BARROS ${ }^{5}$, Ivonete SILVA, \\ José Huygens Parente GARCIA ${ }^{7}$ and Edison Roberto PARISE ${ }^{7}$
}

\begin{abstract}
Space-occupying lesions of the liver may be cystic or solid. Ultrasonography is an extremely useful method for initial screening, and suffices for diagnosis of simple hepatic cysts. Complex cysts and solid masses require computed tomography or magnetic resonance imaging for confirmation. Wide surgical excision is indicated in cystadenoma or cystadenocarcinoma. Clinical and epidemiological data are important, as nodules in noncirrhotic livers are more likely to be benign. Hemangiomas, the most common benign tumors, require no follow-up after diagnostic confirmation if they are small and asymptomatic. Patients with giant, symptomatic hemangiomas or compression of adjacent structures should be referred to hepatobiliary centers for potential surgery. The genetic heterogeneity of hepatocellular adenomas and their epidemiology and prognosis prompted classification of these tumors into four subtypes based on histology and immunohistochemistry. The major complications of hepatocellular adenomas are rupture with bleeding and malignant transformation. Rupture occurs in approximately $30 \%$ of cases. The main risk factors are tumor size $>5 \mathrm{~cm}$ and inflammatory subtype. Hepatocellular adenomas may enlarge during pregnancy due to marked hormonal stimulation. As oral contraceptive pills and anabolic steroids have been associated with hepatocellular adenomas growth, particularly of the hepatocyte nuclear factor-1alfa subtype, these drugs should be discontinued. Focal nodular hyperplasia is the second most common benign tumor of the liver. It is most frequent in women aged 20 to 60 , and $70 \%$ to $90 \%$ of cases are asymptomatic. In the absence of a central scar and/or other hallmarks of Focal nodular hyperplasia, with uncertainty between this diagnosis and hepatocellular adenoma, liver-specific contrast agents are indicated.
\end{abstract}

HEADINGS - Hepatic cysts. Hemangioma. Hepatocellular adenoma. Focal nodular hyperplasia.

\section{INTRODUCTION}

In recent decades, major advancements in imaging techniques have made possible the relatively safe, confident, and early diagnosis of benign and malignant tumors of the liver. Ultrasonography is a readily accessible, widely used, and extremely valuable method for initial screening of hepatic nodules. Space-occupying lesions of the liver may be cystic or solid. Whereas cystic lesions (particularly simple hepatic cysts) do not require further radiologic investigation, solid lesions are often best examined at computed tomography $(\mathrm{CT})$ or magnetic resonance imaging $(\mathrm{MRI})^{(1)}$.

Radiologic investigation of focal hepatic lesions should always be performed using high-resolution scanners and dynamic techniques, i.e., contrast-enhanced imaging that enables assessment of the various stages of vascular filling and emptying, during both the arterial and portal phases. Therefore, the technical quality of the scanner and the expertise of the interpreting radiologist are essential for proper diagnosis. In ultrasonography, in addition to technical factors, operator experience also plays an essential role, which makes its findings extremely "operator-dependent", particularly for initial lesions or small tumors - i.e., in the early stages of the disease, which is a critical time for detection of malignant tumors.

Clinical and epidemiological data also play an important role in the investigation of liver tumors, although the vast majority of these lesions are asymptomatic. Cirrhosis is the single most important risk factor for the development of primary hepatic neoplasms; it is present in approximately $90 \%$ of patients with hepatocellular carcinoma. Therefore, nodules identified in non-cirrhotic livers are far more likely to be benign. Nevertheless, this does not mean that benign nodules cannot arise in cirrhotic livers or that hepatocellular carcinoma does not occur in otherwise healthy livers.

Declared conflict of interest of all authors: none

Disclosure of funding: no funding received

${ }^{1}$ Faculdade de Medicina, Universidade de São Paulo, SP, Brasil; ${ }^{2}$ Universidade Federal do Maranhão, MA, Brasil; ${ }^{3}$ Universidade Federal do Sergipe, SE, Brasil; ${ }^{4}$ Universidade Federal da Bahia, BA, Brasil; ${ }^{5}$ Hospital Português de Recife, PE, Brasil; ${ }^{6}$ Universidade Federal de São Paulo, SP, Brasil; ${ }^{7}$ Universidade Federal do Ceará,CE, Brasil. Correspondence: Edna Strauss. Sociedade Brasileira de Hepatologia. Av. Brigadeiro Faria Lima, 2391, andar 10 -São Paulo, SP, Brasil. E-mail: ednastrauss@gmail.com 
Benign tumors of the liver may be classified by their origin. Hepatocellular adenoma and focal nodular hyperplasia are of hepatocyte origin, whereas simple hepatic cysts, cystadenomas, and polycystic liver disease arise from the biliary epithelium, and hemangiomas originate from mesenchymal tissue ${ }^{(2,3)}$.

In an attempt to disseminate knowledge in hepatology to the broader medical community, through this review, the Brazilian Society of Hepatology presents its latest recommendations for the diagnosis and management of hepatic cysts and of the three most common benign tumors of the liver: hepatic hemangioma, focal nodular hyperplasia, and hepatocellular adenoma.

\section{Cystic lesions of the liver}

Hepatic cysts are congenital biliary lesions caused by the progressive dilatation of biliary microhamartomas that do not communicate with the biliary tree. The population-wide prevalence of these lesions ranges from $1.6 \%$ to $18 \%(4,5)$. The vast majority of cysts are benign; however, the possibility of premalignant or malignant lesions, such as cystadenoma and cystadenocarcinoma, must be evaluated. Cystic lesions of the liver are usually found incidentally, during abdominal imaging, as most are asymptomatic or oligosymptomatic ${ }^{(6)}$.

The major cystic lesions of the liver are simple cysts, hydatid cysts, polycystic liver disease, cystadenoma, and cystadenocarcinoma. Ultrasound has $90 \%$ sensitivity and specificity for diagnosis of these lesions ${ }^{(7)}$. There is no specific treatment, unless symptoms are present.

Hydatid cysts are caused by infection with Echinococcus granulosus or Echinococcus multilocularis, cestode parasites with a low prevalence in developed countries ${ }^{(8)}$, but ubiquitous in the Far South and North of Brazil. Echinococci spread through the contaminated excreta of animals such as dogs and foxes, among others. Diagnosis is based on clinical findings (epidemiologic data, fever, right upper quadrant pain, chest pain, and dyspnea) and echinococcus-specific serology. Pharmacotherapy with albendazole, mebendazole, or praziquantel can cure up to two-thirds of patients with hydatid disease, but recurrence is common after discontinuation of treatment. Watchful waiting suffices for smaller cysts, but in larger lesions, injection of $90 \%$ ethanol or $15 \%$ saline solution is superior to surgical treatment $t^{(9)}$. The World Health Organization advocates the PAIR (puncture-aspiration-injection-reaspiration) procedure ${ }^{(10)}$.

Cystadenomas are considered premalignant lesions, although the exact mechanism of their malignant transformation remain unknown. They account for only $5 \%$ of cystic liver lesions ${ }^{(5)}$. The characteristic imaging appearance of cystadenoma and cystadenocarcinoma is an irregular, oval lesion with internal septations and calcifications, which enhance on contrast CT and MRI ${ }^{(11)}$. Cystadenoma and cystadenocarcinoma are indistinguishable on imaging alone. In both cases, the treatment of choice is surgical resection.

Polycystic liver disease is defined by the presence of at least 20 hepatic lesions ${ }^{(12)}$. It is genetic in origin and usually co-occurs with renal cysts. Diagnosis is made by simple imaging modalities, such as ultrasonography. Treatment is not indicated, unless massive lesions are present which may cause mechanical compression of adjacent organs or symptoms that interfere with quality of life. Laparoscopic unroofing is limited by the presence of multiple, non-communicating cysts; larger lesions may be aspirated and fenestrated. Patients with exceedingly severe disease, when the liver is so large as to obliterate the entire abdominal cavity or cause abdominal compartment syndrome, may be candidates for liver transplantation $^{(13)}$. Figure 1 depicts a chart with diagnostic and therapeutic recommendations for cystic lesions detected by ultrasound

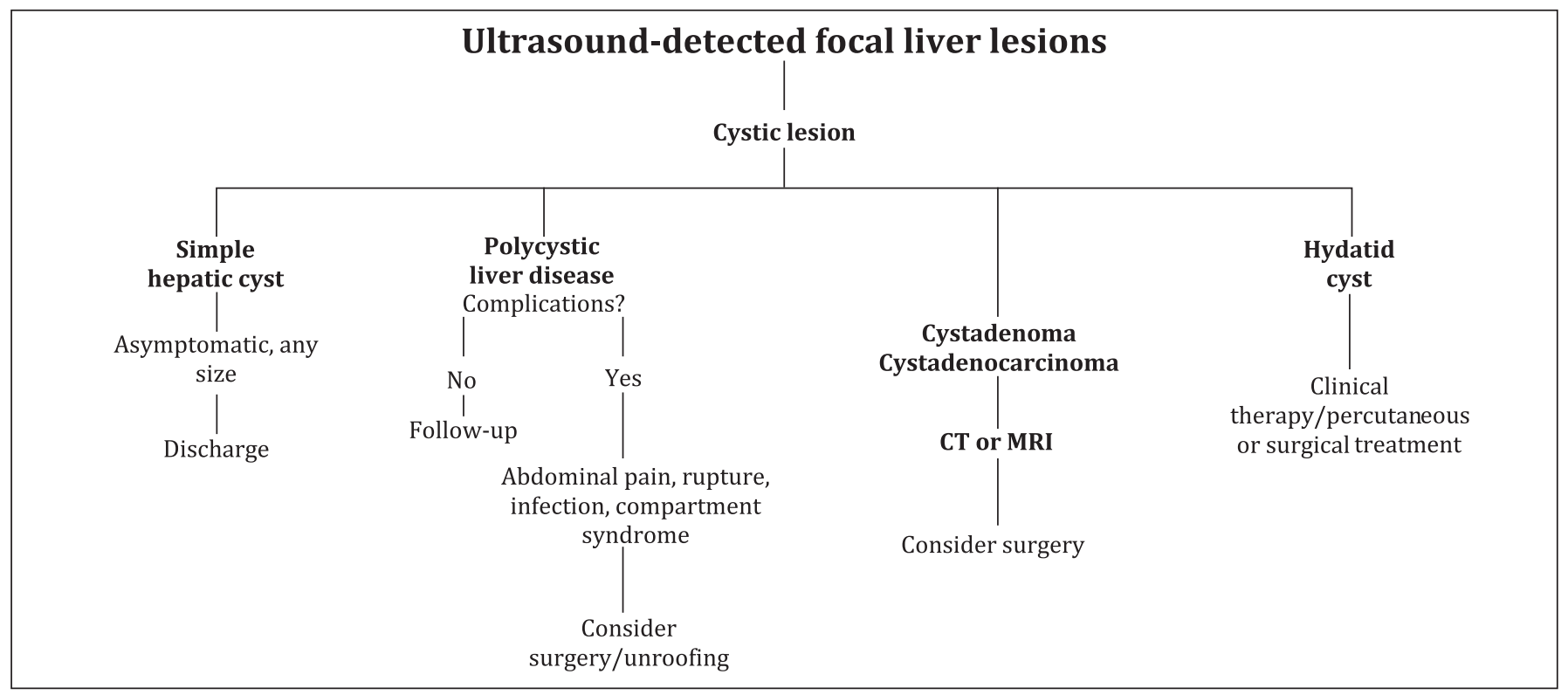

FIGURE1. Practical chart for diagnostic and therapeutic management of ultrasound-detected cystic liver lesions US: ultrasound; CT: computed tomography; MRI: magnetic resonance imaging. 


\section{Recommendations}

- The diagnosis of hepatic cysts may be established by ultrasonography.

- Asymptomatic simple cysts do not require periodic follow-up.

- In the presence of multiple cysts or polycystic liver with symptoms indicative of adjacent organ involvement, surgical management is optimal, with unroofing or fenestration of larger cysts.

- In suspected cystadenoma or cystadenocarcinoma, documented by CT or MRI, wide surgical excision is indicated.

- Hydatid cysts, most common in the Far South and North of Brazil, require adequate clinical management. Percutaneous PAIR (puncture-aspiration-injectionreaspiration) should precede any attempt at more radical surgery, to be analyzed on a case-by-case basis.

\section{Hepatic hemangiomas}

Hemangiomas are the most common benign tumors of the liver. They are composed of multiple blood vessels lined by a single layer of endothelial cells within a thin, fibrous stroma $^{(14)}$. Hepatic hemangiomas are considered congenital vascular malformations or hamartomas; they expand by vascular ectasia rather than by hyperplasia or hypertrophy.

Most patients with hepatic hemangioma are asymptomatic and have their tumor detected incidentally during routine imaging or investigation of other conditions. Hemangiomas may present with a variety of sizes and may be solitary or multiple. The concept of giant hemangioma has been changing in recent years. Some authors in the 1970 s considered hemangiomas larger than 4 or $5 \mathrm{~cm}$ as giant ${ }^{(14,15)}$, whereas a more recent and widely accepted criterion for treatment regards tumors $\geq 10 \mathrm{~cm}$ in size as such ${ }^{(16)}$.

When patients present with symptoms, other causes such as dyspepsia and functional abdominal pain must be ruled out, although massive hemangiomas may compress adjacent organs and structures and cause symptoms such as abdominal pain and early satiety ${ }^{(17,18)}$. Acute abdominal pain may indicate thrombosis or intratumoral bleeding with distension of Glisson's capsule; in acute thrombosis, there may also be fever and altered liver function tests ${ }^{(19)}$. Another rare presentation is hemobilia secondary to rupture into the biliary tree ${ }^{(20)}$.

Physical examination is generally normal. Exceptionally, an enlarged liver or palpable mass may be present in patients with very large hemangiomas. As a rule, liver function tests are within normal limits, unless there are complications such as thrombosis, bleeding, or compression of the biliary tract. In the vast majority of cases, hemangiomas remain stable over time; significant growth may occur, but only rarely. Rupture, whether spontaneous or due to blunt trauma, is exceedingly unusual ${ }^{(21,22)}$. The Kasabach-Merritt syndrome is another rare but well-established complication of giant hemangiomas, characterized by a combination of vascular tumor and consumptive coagulopathy. It is most frequent in children and may progress to disseminated intravascular coagulation. Patients uniformly present with severe thrombocytopenia, low levels of fibrinogen, and high levels of fibrin degradation products due to secondary fibrinolysis and microangiopathic hemolysis ${ }^{(23)}$.

On abdominal ultrasonography, hemangiomas usually present as a hyperechoic nodule with posterior acoustic enhancement. However, they may be hypoechoic if on a background of marked steatosis. Other liver lesions may have a similar appearance on ultrasound; therefore, supplemental contrast-enhanced imaging, such as abdominal CT or MRI, is recommended. If the patient has no risk factors for primary or secondary neoplasms, ultrasound was performed by an experienced technician, and the nodule exhibits all of the typical features of hemangioma, one may forgo additional imaging and perform follow-up ultrasound after 3 or 6 months instead. Only $0.47 \%$ of nodules diagnosed as typical hemangiomas on ultrasound were later found to represent neoplasms ${ }^{(24)}$.

Computed tomography should be performed in a multidetector scanner, with intravenous contrast. In the noncontrast phase, hemangiomas present as a well-defined, hypoattenuating mass, sometimes $(10 \%)$ containing calcifications. Contrast uptake is characterized by increased peripheral enhancement in the early phase, followed by a centripetal "fill-in" pattern during the delayed phase. A nodular or globular enhancement pattern, representative of venous lakes, is seen in up to $94 \%$ of hemangiomas larger than $4 \mathrm{~cm}$, whereas very small hemangiomas may not exhibit this typical pattern ${ }^{(25,26)}$.

Magnetic resonance imaging is a highly precise, noninvasive modality for diagnosis of hepatic hemangiomas, with $\sim 90 \%$ sensitivity and $91 \%-99 \%$ specificity. The typical appearance of a hemangioma on MRI is that of a smooth, homogeneous, well-demarcated mass, hypointense on T1 and hyperintense on T2-weighted sequences ${ }^{(26,27)}$. The presence of fibrosis within the tumor is visualized as hypointense areas on T2 imaging. As in CT imaging, this progressive centripetal fill-in pattern is typical of the majority of hemangiomas $>2 \mathrm{~cm}$ in size; tumors smaller than $2 \mathrm{~cm}$ may exhibit homogeneous contrast filling during the initial phase. Small hemangiomas that exhibit rapid, uniform contrast uptake are sometimes indistinguishable from hypervascular metastases and hepatocellular carcinoma ${ }^{(27)}$. Despite its high specificity, the technetium-99m $\left.{ }^{99 \mathrm{~m}} \mathrm{Tc}\right)$-labeled red blood cell scan has fallen into disuse, as has hepatic angiography. Needle core biopsy carries a risk of life-threatening bleeding ${ }^{(25,26)}$, and should only be considered in rare cases in which a diagnosis cannot be established conclusively despite the use of multiple imaging modalities and a suspicion of malignancy remains.

Treatment of hepatic hemangiomas is usually conservative. There is no consensus in the literature as to the need for continued follow-up of tumors $\leq 5 \mathrm{~cm}$ in size; yearly or twice-yearly follow-up is recommended for patients with lesions $>5 \mathrm{~cm}$. When tumors are asymptomatic, the risk of bleeding is too low to justify prophylactic resection. Patients with pain or symptoms indicative of extrinsic compression of adjacent structures should be considered candidates for surgical resection, as long as other potential causes of these 
symptoms have been ruled out ${ }^{(23)}$. Well-established indications for surgery include rupture with intraperitoneal bleeding, massive hemangiomas causing debilitating symptoms, or inability to rule out malignancy on imaging. Four surgical methods are available for the treatment of hepatic hemangioma: liver resection, enucleation, hepatic artery ligation, and liver transplantation. Nonsurgical options include hepatic artery embolization and radiation therapy. Embolization has been used for management of acute bleeding, symptom relief, and to debulk large hemangiomas prior to surgical resection ${ }^{(28-30)}$

Small hepatic hemangiomas are unlikely to develop complications during pregnancy or oral contraceptive pill (OCP) use. Conservative monitoring during pregnancy is advisable for patients with large tumors, but the presence of hepatic hemangioma is no contraindication to oral hormonal contraception.

\section{Recommendations}

- A finding of hepatic nodule(s) consistent with hemangioma on ultrasound should be confirmed by contrast-enhanced CT or MRI.

- At hepatobiliary centers of excellence where there is absolute certainty of technical quality and professional skill, radiologic confirmation of hemangioma may be unnecessary, as long as the patient has no known risk factors.

- Once the diagnosis has been established conclusively, there is no need for systematic follow-up of asymptomatic patients with small nodules.

- Yearly or twice-yearly follow-up ultrasound is recommended for patients with hemangiomas $>5 \mathrm{~cm}$ in size.

- Patients with hemangioma should be informed of the benign nature of their tumor and that it may very rarely enlarge or develop complications, but has no potential whatsoever for malignant transformation.

- In the event of rare complications such as rupture (spontaneous or traumatic) or consumptive coagulopathy (Kasabach-Merritt syndrome), surgical treatment is necessary.

- Patients with symptomatic giant hemangiomas or those presenting with compression of adjacent structures should be referred to a hepatobiliary center for assessment of surgical or nonsurgical treatment options, such as enucleation, liver resection, arterial embolization, or radiofrequency ablation, the efficacy of which remains unconfirmed.

- The use of oral contraceptive pills (OCPs) or other hormonal therapies is not contraindicated in patients with hemangiomas.

\section{Hepatocellular adenoma}

Hepatocellular adenomas (HCAs) are the third most prevalent benign neoplasm of the liver(31). They are unusual overall, occurring most frequently in women between the ages of 20 and 44 .

Traditionally, HCAs have been associated with use of estrogen-containing OCPs. The incidence of HCA is estimated to be 30 -fold higher among women who take OCPs than in women who do not ${ }^{(32)}$, and it is directly associated with dose and duration of OCP use ${ }^{(33)}$. Discontinuation of hormonal contraception usually leads to HCA regression ${ }^{(34)}$. HCAs have also been associated with anabolic androgenic steroid use ${ }^{(35)}$, genetic disorders such as glycogen storage disease types I and $\mathrm{III}^{(36)}$, and more recently, the metabolic syndrome and obesity ${ }^{(37)}$.

HCAs are generally asymptomatic and carry a favorable prognosis, but the potential exists for complications such as bleeding and malignant transformation ${ }^{(38)}$. In the majority of patients $(70 \%-80 \%)$, HCA occurs as a solitary lesion, but multiple nodules may occur; the presence of $\geq 10 \mathrm{HCAs}$ is known as hepatic adenomatosis ${ }^{(39)}$.

The genetic heterogeneity of HCAs and its relationship with epidemiologic and prognostic factors has prompted molecular classification of adenomas on the basis of histologic and immunohistochemical findings. Four subtypes have been defined, as described in a recent review ${ }^{(40)}$. These subtypes are: a) HCA associated with an inactivating mutation of the hepatocyte nuclear factor-1alfa (HNF1A) tumor suppressor gene. This subtype occurs almost exclusively in women taking OCPs, is one of the most common, accounting for $35 \%-40 \%$ of cases, and is unlikely to cause complications; b) $\beta$-catenin-mutated HCA, which is associated with mutations that activate the $\beta$-catenin gene and facilitate cell replication. These adenomas are more common in men, account for $10 \%-15 \%$ of cases, and carry an increased risk of malignant transformation; c) inflammatory (or steatotic) HCA, in which the role of genetic mutations is unclear. They are more common in women and usually associated with obesity and the metabolic syndrome. Inflammatory HCAs account for $40 \%-55 \%$ of cases, and carry a higher risk of rupture and bleeding; and d) indeterminate HCA, not associated with any known mutations or specific histologic and prognostic features, accounting for $10 \%$ of cases.

The first three subtypes are associated with specific MRI findings that can facilitate their classification and, consequently, help clinicians and patients make treatment decisions $^{(41)}$. Therefore, MRI is the imaging modality of choice for diagnosis of HCA. As adenomas are hypervascular, percutaneous liver biopsy is not usually recommended, due to the high risk of bleeding and to the fact that specimen material is often insufficient for definitive diagnosis ${ }^{(42)}$. It may, however, be indicated for histopathologic and immunohistochemical examination when imaging modalities are unable to distinguish HCA from other lesion types. In these cases, biopsy can help establish subtype and define management ${ }^{(43)}$.

The main complications of HCA are rupture with bleeding and malignant transformation. Rupture occurs in approximately $30 \%$ of cases $^{(38,44)}$. The leading risk factors are tumor size $>5 \mathrm{~cm}^{(45,46)}$, the inflammatory subtype ${ }^{(43)}$, and pregnancy $^{(47)}$. During pregnancy, enlargement of HCAs may occur, a phenomenon that has been attributed to marked hormonal stimulation and requires individualized manage$\operatorname{ment}^{(48)}$. 
Malignant transformation may occur in up to $8 \%$ of cases and is associated with tumor size $>5 \mathrm{~cm}$. A systematic review published in $2010^{(49)}$ found only three cases of malignant transformation of tumors less than $5 \mathrm{~cm}$ in size. Other associated factors are male sex, regardless of tumor size (the risk of malignant transformation is 5 to 10 times greater in men than in women), and the '-catenin-activated subtype ${ }^{(50)}$

HCAs may be symptomatic. Upper abdominal pain is the most common manifestation ${ }^{(44)}$. Asymptomatic patients with HCAs discovered incidentally on ultrasound examination should undergo MRI for diagnostic confirmation and definition of subtype ${ }^{(51)}$. The use of liver-specific contrast agents is preferred, especially if there is diagnostic uncertainty between HCA and focal nodular hyperplasia ${ }^{(52)}$. When surgical resection is not indicated, follow-up contrast-enhanced imaging should be performed every 6 months.

As well as pregnancy, use of OCPs and anabolic androgenic steroids is also associated with growth of HCAs, particularly those of the HNF1A subtype. Therefore, these agents should be discontinued if in use ${ }^{(43)}$. In women of childbearing age with large HCAs $(>5 \mathrm{~cm})$, it is preferable that adenomas be resected before pregnancy. The high risk of malignant transformation of HCAs in male patients means that surgical resection is always recommended in men, regardless of tumor size ${ }^{(49)}$. Figure 2 depicts a chart with diagnostic and therapeutic recommendations for solid lesions detected by ultrasound.

\section{Recommendations}

- The imaging modality of choice for suspected cases of hepatocellular adenoma is MRI, which may also define disease subtype.
- Percutaneous liver biopsy should be reserved for cases of diagnostic uncertainty in which definition of management is dependent on biopsy findings.

- OCPs or anabolic androgenic steroids should be discontinued if in use.

- Surgical resection is indicated in women of childbearing age with lesions $\geq 5 \mathrm{~cm}$ and in men, regardless of lesion size.

- As gestation may lead to growth of hepatocellular adenomas, resection should be offered to women with large nodules (even if $<5 \mathrm{~cm}$ ) who wish to become pregnant.

- If surgical intervention is not indicated, the progression of hepatocellular adenomas should be monitored by follow-up imaging every 6 months.

\section{Focal nodular hyperplasia and liver-specific contrast agents}

Focal nodular hyperplasia $(\mathrm{FNH})$ is a benign liver lesion, once considered a neoplasm (specifically, a form of hamartoma). Now, however, the most commonly accepted hypothesis for its pathogenesis is a hyperplastic response to hyperperfusion or ischemia in the presence of vascular injury of an anomalous artery located within the lesion ${ }^{(53)}$. Its characteristic feature is a thick central scar with radiating septa. In addition to hepatic cords, there may be numerous biliary ductules, of hepatocyte origin, which do not communicate with the biliary tree. The FNH lesion is lobulated and well-demarcated, but not encapsulated. Unlike HCA, FNH features cells of the macrophage mononuclear phagocyte system within its sinusoids ${ }^{(54)}$.

FNH is the second most common benign tumor, and is most prevalent in women between the ages of 20 and 60 . It is asymptomatic in $70 \%-90 \%$ of cases and usually detected

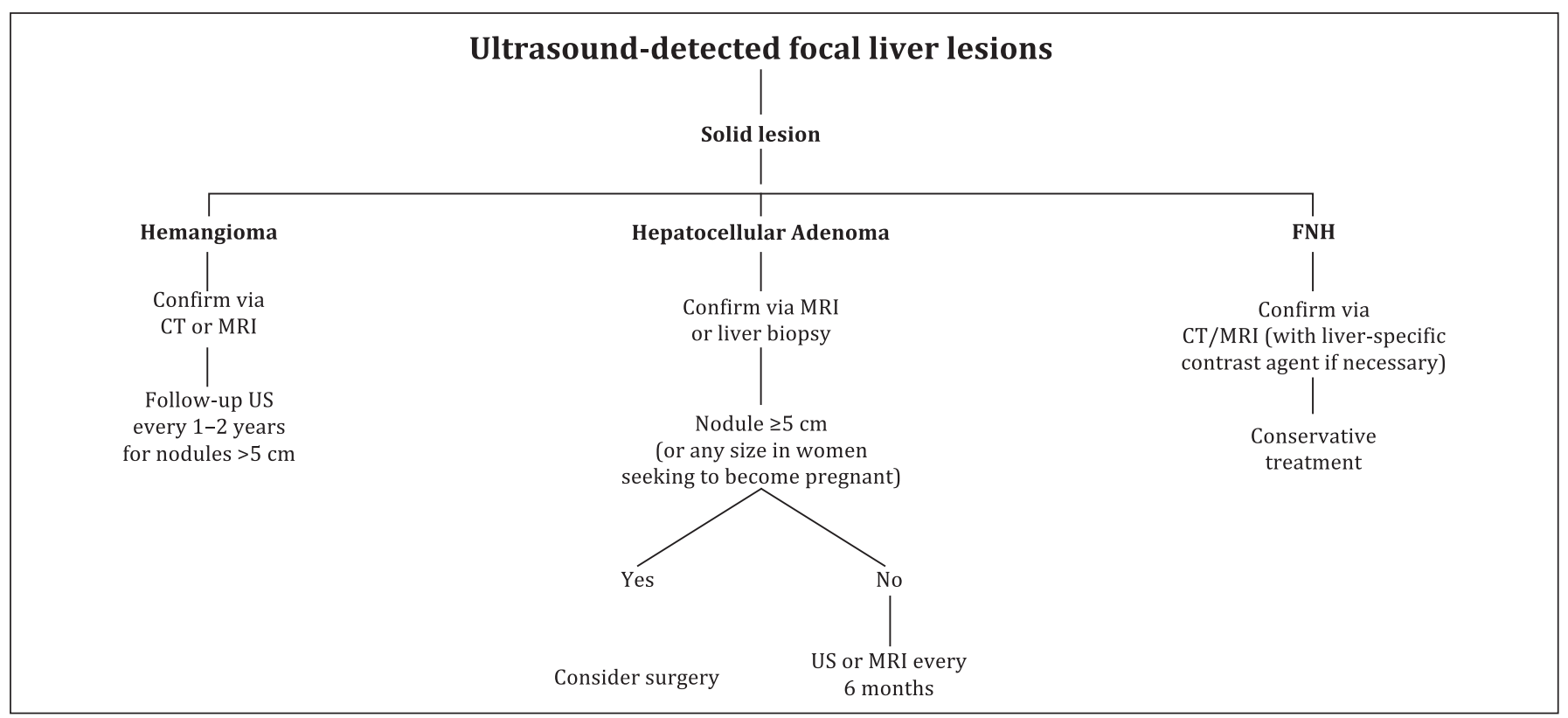

FIGURE 2. Practical chart for diagnostic and therapeutic management of ultrasound-detected solid liver lesions US: ultrasound; CT: computed tomography; MRI: magnetic resonance imaging; FNH: focal nodular hyperplasia. 
incidentally on imaging. Its potential association with estrogens is controversial and certainly less evident than that observed in adenomas. The presence of a classic central scar and other characteristic features on MRI enables definitive diagnosis in the majority of patients. In addition to its frequently asymptomatic nature, FNH is not usually associated with complications such as bleeding, nor does it have the potential for malignant transformation ${ }^{(55)}$.

Clinical experience and a review of the literature note that, rarely, cases of the fibrolamellar variant of hepatocellular carcinoma are confused with or diagnosed in a background of $\mathrm{FNH}^{(56,57)}$; hence, the need for confident radiologic diagnosis and proper clinical follow-up of all patients with FNH. In less than $20 \%$ of cases, symptoms may develop and the tumor may decrease in size over time. Some cases of FNH may present with multiple lesions or coexist with hemangiomas or hepatic cysts. Cases formerly classified as a purported variant known as "telangiectatic FNH", with the potential for bleeding, are now more properly classified as inflammatory $\mathrm{HCAs}^{(58)}$.

The differential diagnosis of solid liver lesions, whether small or large and regardless of clinical and radiologic evidence of benign etiology, may be challenging. The two most common diagnostic possibilities are FNH and HCA. Recently, the use of liver-specific (or hepatocyte-specific) contrast agents has been recommended to distinguish between these two types of tumor, which have distinct clinical courses and should be managed accordingly ${ }^{(59)}$.

The main contrast agents used for detection of focal liver lesions are gadolinium-DTPA (Gd-DTPA) and its derivatives gadobenate and gadoxetic acid (Gd-EOB-DTPA). Gadoxetic acid, the only one of these agents approved for use in Brazil to date, is considered a liver-specific contrast medium, as it is taken up by functionally active liver cells (hepatocytes or biliary cells) and can provide information on liver anatomy and function. Its elimination is approximately $50 \%$ renal and $50 \%$ hepatobiliary ${ }^{(60)}$.

Though scarce, comparative studies suggest that liver-specific contrast is vastly superior to Gd-DTPA in distinguishing $\mathrm{HCA}$ from $\mathrm{FNH}^{(61-63)}$. A prospective study of histopathologic analyses of 54 focal liver lesions larger than $2 \mathrm{~cm}(24 \mathrm{FNH}$ and $28 \mathrm{HCA}$ ) found that, as compared with Gd-DTPA, Gd-EOB-DTPA was associated with increased diagnostic sensitivity for both HCA (50\% vs $96 \%)$ and FNH (68\% vs $96 \%$ ). Bleeding, fat, and glycogen were more commonly present in adenomas, whereas a central scar was predictive of $\mathrm{FNH}^{(62)}$. A retrospective histopathologic study of 115 focal liver lesions (44 FNH and $71 \mathrm{HCA}$ ) concluded that the presence of contrast uptake of FNH vs. hypointensity of HCAs in the hepatobiliary phase yielded an accuracy of $92 \%$ for differential diagnosis of these lesions ${ }^{(63)}$.

\section{Recommendations}

- A diagnosis of FNH suggested by ultrasound findings should be confirmed by dynamic CT or MRI.

- If central scars and/or other signs indicative of FNH are absent and there is diagnostic uncertainty between $\mathrm{HCA}$ and FNH, the use of liver-specific contrast agents is indicated.

- If a diagnosis of FNH is confirmed, conservative management is indicated. There is no specific treatment.

- Follow-up imaging is recommended for patients with FNH, who are generally asymptomatic. Control scans may be performed every 6 months to 2 years, depending on the disease course.

- Exceptionally large nodules associated with symptoms or compression of adjacent structures should be considered for surgical resection.

Strauss E, Ferreira ASP, França AVC, Lyra AC, Barros FMR, Silva I, Garcia JHP, Parise ER. Diagnóstico e tratamento de nódulos hepáticos benignos: recomendações da Sociedade Brasileira de Hepatologia. Arq Gastroenterol. 2015(Supl 1):47-54.

RESUMO - As lesões que ocupam espaço no fígado podem ser císticas ou sólidas. A ultrassonografia é extremamente útil como rastreamento inicial, bastando como método diagnóstico em casos de cistos simples. Em cistos complexos e em nódulos sólidos é necessária a complementação diagnóstica com tomografia computadorizada ou ressonância magnética. Em casos de cistadenoma ou cistadenocarcinoma, a ampla retirada cirúrgica está indicada. Dados clínico-epidemiológicos são importantes, já que nódulos em fígados não-cirróticos têm maiores probabilidades de serem benignos. Para os hemangiomas, tumores benignos mais frequentes, após a confirmação diagnóstica não existe necessidade de acompanhamento sistemático quando os nódulos são pequenos e assintomáticos. Hemangiomas gigantes sintomáticos ou comprimindo órgãos vizinhos devem ser encaminhados a centros de referência para avaliação de intervenção cirúrgica. A heterogeneidade genética nos adenomas hepatocelulares bem como características epidemiológicas e prognósticas motivou sua classificação em quatro subtipos, com base em achados histológicos e de imunohistoquímica. As principais complicações que ocorrem com o adenomas hepatocelulares são ruptura com hemorragia e transformação carcinomatosa. A primeira ocorre em cerca de $30 \%$ dos casos e o principal fator de risco para esta complicação são tumores maiores do que $5 \mathrm{~cm}$, do subtipo adenoma hepatocelular inflamatório. Durante a gravidez pode ocorrer aumento do adenoma hepatocelular, atribuído a intenso estimulo hormonal. Como o uso de anticoncepcionais orais ou esteroides anabolizantes está relacionado com crescimento dos adenomas, principalmente no subtipo hiperplasia nodular focal $1 \mathrm{~A}$, esses medicamentos devem ser suspensos. A hiperplasia nodular focal é o segundo tumor benigno mais frequente, mais comum nas mulheres entre 20 e 60 anos, sendo assintomáticos em 70\% a 90\% dos casos. Na ausência de lesão cicatricial central e/ou outros sinais sugestivos de hiperplasia nodular focal, havendo dúvida diagnóstica com adenoma hepatocelular, o uso de contrastes hepatespecíficos está indicado.

DESCRITORES - Cistos hepáticos. Hemagioma. Adenoma hepatocelular. Hiperplasia nodular focal. 


\section{REFERENCES}

1. Bartolozzi C, Cioni D, Donati F, Lencioni R. Focal liver lesions: MR imaging-pathologic correlation. Eur Radiol. 2001;11:1374-88.

2. Pugliese V, Herman P, Gayotto LC. Lesões Tumorais Benignas de Origem Hepatocelular. In: Gayotto LCC, Alves VAF, eds. Doenças do Figado e Vias Biliares. Volume 2. São Paulo: Editora Atheneu, 2001; 977-983.

3. Lantinga MA, Gevers TJ, Drenth JP. Evaluation of hepatic cystic lesions. World J Gastroenterol. 2013;19:3543-54

4. Chiche L, Adam JP. Diagnosis and management of benign liver tumors. Semin Liver Dis. 2013;33:236-47.

5. Caremani M, Vincenti A, Benci A, Sassoli S, Tacconi D. Ecographic epidemiology of non-parasitic hepatic cysts. J Clin Ultrasound. 1993;21:115-8.

6. Hai S, Hirohashi K, Uenishi T, Yamamoto T, Shuto T, Tanaka H, Kubo S, et al. Surgical management of cystic hepatic neoplasms. J Gastroenterol. 2003;38:759-64.

7. Taylor KJ, Richman TS. Diseases of the liver. Semin Roentgenol. 1983;18:94-101

8. Nunnari G, Pinzone MR, Gruttadauria S, Celesia BM, Madeddu G, Malaguarnera G, Pavone P, et al. Hepatic echinococcosis: clinical and therapeutic aspects. World J Gastroenterol. 2012;18:1448-1458.

9. Ormeci N. PAIR vs Ormeci technique for the treatment of hydatid cyst. Turk J Gastroenterol. 2014;25:358-64

10. Eckert J. WHO/OIE manual on echinococcosis in humans and animals: a public healthe problem of global concern. World Organization for Animal Health. 2001:20-72.

11. Delis SG, Touloumis Z, Bakoyiannis A, Tassopoulos N, Paraskeva K, Athanassiou K, Safioleas M, et al. Intrahepatic biliary cystadenoma: a need for radica resection. Eur J Gastroenterol Hepatol. 2008;20:10-14.

12. Van Keimpema L, De Koning DB, Van Hoek B, Van Den Berg AP, Van Oijen MG, De Man RA, Nevens F, et al. Patients with isolated polycystic liver disease referred to liver centres: clinical characterization of 137 cases. Liver Int. 2011:31:92-8.

13. Abu-Wasel B, Walsh C, Keough V, Molinari M. Pathophysiology, epidemiology, classification and treatment options for polycystic liver diseases. World J Gastroenterol. 2013;19:5775-86.

14. Adam YG, Huvos AG, Fortner JG. Giant hemangiomas of the liver. Ann Surg 1970;172:239-45

15. Grieco MB, Miscall BG. Giant hemangiomas of the liver. Surg Gynecol Obstet 1978;147:783-7.

16. van Tilborg AA, Nielsen $K$, Scheffer HJ, van den Tol $P$, van Waesberghe JH, Sietses C, Meijerink MR. Bipolar radiofrequency ablation for symptomatic gian $(>10 \mathrm{~cm})$ hepatic cavernous haemangiomas: initial clinical experience. Clin Radiol. 2013;68:e9-e14.

17. Aydin C, Akbulut S, Kutluturk K, Kahraman A, Kayaalp C, Yilmaz S. Giant hepatic hemangioma presenting as gastric outlet obstruction. Int Surg. 2013;98:19 23.

18. Losanoff JE, Millis JM. Liver hemangioma complicated by obstructive jaundice. Am J Surg. 2008;196:e3-4

19. Pateron D, Babany G, Belghiti J, Hadengue A, Menu Y, Flejou JF, Erlinger S, et al. Giant hemangioma of the liver with pain, fever, and abnormal liver tests. Report of two cases. Dig Dis Sci. 1991;36:524-7.

20. Birth M, Ortlepp J, Bontikous S, Amthor M, Weiser HF, Bruch HP. Intermitten activity-induced hemobilia caused by liver hemangioma. Dig Surg. 2000;17:292-6.

21. Gandolfi L, Leo P, Solmi L, Vitelli E, Verros G, Colecchia A. Natural history of hepatic haemangiomas: clinical and ultrasound study. Gut. 1991;32:677-80.

22. Okano H, Shiraki K, Inoue H, Ito T, Yamanaka T, Deguchi M, Sugimoto K, et al. Natural course of cavernous hepatic hemangioma. Oncol Rep. 2001;8:411-4

23. Hoekstra LT, Bieze M, Erdogan D, Roelofs JJ, Beuers UH, van Gulik TM. Management of giant liver hemangiomas: an update. Expert Rev Gastroenterol Hepatol. 2013;7:263-8

24. Leifer DM, Middleton WD, Teefey SA, Menias CO, Leahy JR. Follow-up of patients at low risk for hepatic malignancy with a characteristic hemangioma at US. Radiology. 2000;214:167-72.

25. Caseiro-Alves F, Brito J, Araujo AE, Belo-Soares P, Rodrigues H, Cipriano A Sousa $\mathrm{D}$, et al. Liver haemangioma: common and uncommon findings and how to improve the differential diagnosis. Eur Radiol. 2007;17:1544-54

26. Klotz T, Montoriol PF, Da Ines D, Petitcolin V, Joubert-Zakeyh J, Garcier JM. Hepatic haemangioma: common and uncommon imaging features. Diagn Interv Imaging. 2013;94:849-59.

27. Cogley JR, Miller FH. MR imaging of benign focal liver lesions. Radiol Clin North Am. 2014:52:657-82.

28. Yamamoto T, Kawarada Y, Yano T, Noguchi T, Mizumoto R. Spontaneous rupture of hemangioma of the liver: treatment with transcatheter hepatic arterial embolization. Am J Gastroenterol. 1991;86:1645-9.
29. Suzuki H, Nimura Y, Kamiya J, Kondo S, Nagino M, Kanai M, Miyachi M Preoperative transcatheter arterial embolization for giant cavernous hemangioma of the liver with consumption coagulopathy. Am J Gastroenterol. 1997;92:688-91.

30. Jiang H, Chen Z, Prasoon P, Wu H, Zeng Y. Surgical Management for Giant live Hemangiomas Greater Than $20 \mathrm{~cm}$ in Size. Gut Liver. 2011:5 228-33.

31. Maillette de Buy Wenniger L, Terpstra V, Beuers U. Focal nodular hyperplasia and hepatic adenoma: epidemiology and pathology. Dig Surg. 2010;27:24-31.

32. Rooks JB, Ory HW, Ishak KG, Strauss LT, Greenspan JR, Hill AP, Tyler CW, Jr. Epidemiology of hepatocellular adenoma. The role of oral contraceptive use. JAMA. 1979;242:644-8

33. Rosenberg L. The risk of liver neoplasia in relation to combined oral contraceptive use. Contraception. 1991;43:643-52.

34. Edmondson HA, Reynolds TB, Henderson B, Benton B. Regression of liver cell adenomas associated with oral contraceptives. Ann Intern Med. 1977;86:180-2.

35. Giannitrapani L, Soresi M, La Spada E, Cervello M, D'Alessandro N, Montalto G. Sex hormones and risk of liver tumor. Ann N Y Acad Sci. 2006;1089·228-36.

36. Labrune P, Trioche P, Duvaltier I, Chevalier P, Odievre M. Hepatocellular adenomas in glycogen storage disease type I and III: a series of 43 patients and review of the literature. J Pediatr Gastroenterol Nutr. 1997:24:276-9.

37. Bioulac-Sage P, Taouji S, Possenti L, Balabaud C. Hepatocellular adenoma subtypes: the impact of overweight and obesity. Liver Int. 2012;32:1217-21

38. Deneve JL, Pawlik TM, Cunningham S, Clary B, Reddy S, Scoggins CR, Martin $\mathrm{RC}$, et al. Liver cell adenoma: a multicenter analysis of risk factors for rupture and malignancy. Ann Surg Oncol. 2009;16:640-8.

39. Greaves WO, Bhattacharya B. Hepatic adenomatosis. Arch Pathol Lab Med. 2008;132:1951-5

40. Dhingra S, Fiel MI. Update on the new classification of hepatic adenomas: clinical, molecular, and pathologic characteristics. Arch Pathol Lab Med. 2014:138:1090-7.

41. Ronot M, Bahrami S, Calderaro J, Valla DC, Bedossa P, Belghiti J, Vilgrain V, et al. Hepatocellular adenomas: accuracy of magnetic resonance imaging and liver biopsy in subtype classification. Hepatology. 2011:53:1182-91.

42. Shaked O, Siegelman ES, Olthoff K, Reddy KR. Biologic and clinical features of benign solid and cystic lesions of the liver. Clin Gastroenterol Hepatol. 2011;9:54762 el-4.

43. Agrawal S, Agarwal S, Arnason T, Saini S, Belghiti J. Management of Hepatocellular Adenoma: Recent Advances. Clin Gastroenterol Hepatol. 2014.

44. van Aalten SM, de Man RA, JN IJ, Terkivatan T. Systematic review of haemorrhage and rupture of hepatocellular adenomas. Br J Surg. 2012;99:911-6.

45. Toso C, Majno P, Andres A, Rubbia-Brandt L, Berney T, Buhler L, Morel P, et al. Management of hepatocellular adenoma: solitary-uncomplicated, multiple and ruptured tumors. World J Gastroenterol. 2005;11:5691-5.

46. Maoz D, Sharon E, Chen Y, Grief F. Spontaneous hepatic rupture: 13-yea experience of a single center. Eur J Gastroenterol Hepatol. 2010;22:997-1000.

47. Bis KA, Waxman B. Rupture of the liver associated with pregnancy: a review of the literature and report of 2 cases. Obstet Gynecol Surv. 1976;31:763-73.

48. Broker ME, Ijzermans JN, van Aalten SM, de Man RA, Terkivatan T. The management of pregnancy in women with hepatocellular adenoma: a plea for an individualized approach. Int J Hepatol. 2012;2012:725735.

49. Stoot JH, Coelen RJ, De Jong MC, Dejong CH. Malignant transformation of hepatocellular adenomas into hepatocellular carcinomas: a systematic review including more than 1600 adenoma cases. HPB (Oxford). 2010;12:509-22.

50. Farges O, Ferreira N, Dokmak S, Belghiti J, Bedossa P, Paradis V. Changing trends in malignant transformation of hepatocellular adenoma. Gut. 2011;60:85-9.

51. Denecke T, Steffen IG, Agarwal S, Seehofer D, Kroncke T, Hanninen EL, Kramme IB, et al. Appearance of hepatocellular adenomas on gadoxetic acid-enhanced MRI. Eur Radiol. 2012;22:1769-75

52. Grazioli L, Bondioni MP, Haradome H, Motosugi U, Tinti R, Frittoli B, Gambarini $\mathrm{S}$, et al. Hepatocellular adenoma and focal nodular hyperplasia: value of gadoxetic acid-enhanced MR imaging in differential diagnosis. Radiology. 2012;262:520-9.

53. Wanless IR, Mawdsley C, Adams R. On the pathogenesis of focal nodular hyperplasia of the liver. Hepatology. 1985;5:1194-200.

54. Sempoux C, Balabaud C, Bioulac-Sage P. Pictures of focal nodular hyperplasia and hepatocellular adenomas. World J Hepatol. 2014;6:580-95.

55. Belghiti J, Cauchy F, Paradis V, Vilgrain V. Diagnosis and management of solid benign liver lesions. Nat Rev Gastroenterol Hepatol;2014.

56. Hamrick-Turner JE, Shipkey FH, Cranston PE. Fibrolamellar hepatocellular carcinoma: MR appearance mimicking focal nodular hyperplasia. J Comput Assist Tomogr. 1994:18:301-4.

57. Imkie M, Myers SA, Li Y, Fan F, Bennett TL, Forster J, Tawfik O. Fibrolamellar hepatocellular carcinoma arising in a background of focal nodular hyperplasia: a report of 2 cases. J Reprod Med. 2005;50:633-7. 
58. Bioulac-Sage P, Rebouissou S, Sa Cunha A, Jeannot E, Lepreux S, Blanc JF, Blanche $\mathrm{H}$, et al. Clinical, morphologic, and molecular features defining socalled telangiectatic focal nodular hyperplasias of the liver. Gastroenterology 2005; $128: 1211-8$

59. Mohajer K, Frydrychowicz A, Robbins JB, Loeffler AG, Reed TD, Reeder SB. Characterization of hepatic adenoma and focal nodular hyperplasia with gadoxetic acid. J Magn Reson Imaging. 2012;36:686-96.

60. Jeong WK, Kim YK, Song KD, Choi D, Lim HK. The MR imaging diagnosis of liver diseases using gadoxetic acid: emphasis on hepatobiliary phase. Clin $\mathrm{Mol}$ Hepatol. 2013;19:360-6.
61. Grazioli L, Morana G, Kirchin MA, Schneider G. Accurate differentiation of focal nodular hyperplasia from hepatic adenoma at gadobenate dimeglumine-enhanced MR imaging: prospective study. Radiology. 2005;236:166-77.

62. Bieze M, van den Esschert JW, Nio CY, Verheij J, Reitsma JB, Terpstra V, van Gulik TM, et al. Diagnostic accuracy of MRI in differentiating hepatocellular adenoma from focal nodular hyperplasia: prospective study of the additional value of gadoxetate disodium. AJR Am J Roentgenol. 2012;199:26-34.

63. Grieser C, Steffen IG, Kramme IB, Blaker H, Kilic E, Perez Fernandez CM, Seehofer D, et al. Gadoxetic acid enhanced MRI for differentiation of FNH and HCA: a single centre experience. Eur Radiol. 2014;24:1339-48. 